\title{
Mule Spinners' Cancer and the Wool Industry
}

\author{
W. R. LEE and JOAN K. McCANN \\ From the Department of Occupational Health, University of Manchester, and \\ Rochdale Industrial Health Service
}

Although mule spinning has been used in the cotton and wool industries for about two centuries, the earliest recorded cases of mule spinners' cancer were not reported until the end of the nineteenth century. From then on the number of cases rapidly increased. Evidence accumulated which strongly suggested that the mineral oil used to lubricate the mule spindles was the cause. It is remarkable that mule spinners' cancer was almost entirely confined to the cotton industry, and the wool industry has escaped with very few cases. This difference has never been satisfactorily explained. Various possibilities related to the personnel, the plant, and the process are examined in this paper.

Mule spinning has been used in the cotton and wool industries for about two centuries. Although mule spinners' cancer has, for many years, been recognized as a hazard to workers on cotton mules, it is virtually unknown in mule spinners in the wool industry. It is interesting to consider why this should be.

At the beginning of the industrial revolution, when the spinning mule was invented, mills sprang up in the small valleys where water power could be harnessed. Traditional agriculture continued in the nearby hills (Davies, 1963). The machines, therefore, were lubricated with the readily available animal oils such as neatsfoot and perhaps sperm oil. In this country mineral oils were developed in the middle of the last century, at first in Derbyshire and then subsequently as shale oil in Scotland. Mineral oil soon replaced animal oil and, by the end of the century, was the only form of lubrication used. In 1876 Joseph Bell published a paper on the occurrence of skin cancer among shale oil workers, and some II years later a case of skin cancer was reported in a cotton mule spinner (Brockbank, 194I).

In I9ro Wilson of Manchester wrote the winning essay in the Tom Jones Prize Essay Competition. He pointed out that, out of 35 patients admitted to the Manchester Royal Infirmary with caneer of the scrotum, 25 were spinners ('mostly mule spinners') and five were labourers, three of whom had been mule spinners. He discussed as possible causes of

Received for publication September 28, 1966. the condition: mechanical factors, dust, grease constituents of the cotton, and repeated trauma. This work was not published until it appeared in I922 as a joint paper by Southam and Wilson, who suggested oil as the cause. The idea was supported by Leitch in 1924 .

A judgement in the Lancashire County Court in r924 deciding that the disease arose 'out of and in the course of employment' and was attributable to mineral oil, caused some anxiety. It was not, however, generally accepted that mineral oil was the responsible agent. Robertson (1962), in a paper to the Manchester Pathological Society, questioned the role of mineral oil. He pointed out that until I905 cotton spinners wore soft white overalls made of fustian which was free from chemicals. After that date there had been a change to "blue overalls of hard cheap material worn next to the skin and supported by an inelastic brace'. He stated that the rough seams at the fork caused slight pressure and friction, about 240 times an hour, at the site where epitheliomata most frequently occurred. However, his views were strongly challenged, several speakers citing cases of multiple epitheliomata occurring in cotton mule spinners on the scrotum, face, and arms, and the appearance of irritative papules' on the skin of the forearms of persons who had left two years before.

In 1926 a committee appointed by the Home Secretary strongly favoured the view that this form of cancer was due to the prolonged action of mineral oils (Home Office, 1926). The idea of coloured overalls being a cause was rejected, for the disease 
TABLE I

Registrar General's Decennial Supplement for ENgland and Wales, I93 I

\begin{tabular}{|c|c|c|c|c|c|c|c|c|c|c|}
\hline & \multicolumn{9}{|c|}{$\begin{array}{l}\text { Spinners and Piecers } \\
\text { (mule, king, cap or flyer) }\end{array}$} & \multirow{3}{*}{$\begin{array}{c}\text { Aggregate } \\
20-65\end{array}$} \\
\hline & \multicolumn{9}{|c|}{ Age Groups } & \\
\hline & $16-$ & $20-$ & $25-$ & $35-$ & $45-$ & $55-$ & $65-$ & $70-$ & $75+$ & \\
\hline $\begin{array}{l}\text { Cotton } \\
\text { Wool }\end{array}$ & $\begin{array}{l}5,317 \\
2,197\end{array}$ & $\begin{array}{l}9,805 \\
1,684\end{array}$ & $\begin{array}{r}11,720 \\
2,567\end{array}$ & $\begin{array}{l}7,159 \\
1,458\end{array}$ & $\begin{array}{l}6,353 \\
1,128\end{array}$ & $\begin{array}{r}4,819 \\
888\end{array}$ & $\begin{array}{r}1,646 \\
305\end{array}$ & $\begin{array}{l}752 \\
173\end{array}$ & $\begin{array}{l}401 \\
136\end{array}$ & $\begin{array}{r}39,856 \\
7,725\end{array}$ \\
\hline
\end{tabular}

had frequently been observed in spinners who had never worn them. The part played by mineral oils was investigated experimentally by Twort and Ing in 1928 and by Twort and Twort in 1931. They concluded that shale oil was the most carcinogenic of those oils which they had investigated, and that the carcinogenicity of petroleum oils, particularly the higher boiling fractions, was less. The carcinogenic properties varied greatly according to the source of the oil.

From I9II to 1938, that is up to some 50 years after the first case had been described, there had been more than 500 deaths from cancer of the scrotum in cotton mule spinners. It is remarkable that in this period there were only three deaths in wool mule spinners (Henry, 1946). Several of the earlier authors had noticed the freedom of wool mule spinners from this disease (Leitch, 1924; Home Office, 1926; Brockbank-quoted in Robertson, 1926; Brockbank and Stopford, 1927).

We may consider various reasons for this remarkable difference in incidence. As the proportion of deaths traced by Henry (1937) in the two industries was 160 in cotton to one in wool, it is important to look at the numbers of men employed in these two occupations. The Registrar General's (1938) census figures for I93 I list piecers and spinners of all sorts, that is, mule, ring, cap and flyer, grouped together, and there were about forty thousand cotton spinners to about seven and a half thousand wool spinners, a ratio of only about five to one. For the decade 1926-35 Henry was able to trace 172 deaths from scrotal cancer among cotton spinners, giving a crude death rate of 4.3 per thousand over the decade. Applying this rate to the wool-spinning population of 7,500 gives an expected incidence of 32 cases in the decade 1926-35, whereas Henry (1946) was able to find only three deaths from the disease in wool mule spinners in the 60-year period ending in 1945. The age structure of the two groups is similar, and so the difference cannot be attributed to a preponderance in cotton spinning of older men who might be in the age group where more cancers would be expected (Table I).

Is it, then, that there was such an overwhelming proportion of mule spinners in the cotton industry compared with the wool industry? This is difficult to answer, but it should be noted that, whilst mule spinning has been declining in the cotton industry since the end of the last century (Irvine, 1935), it has been widely used in the woollen industry and has only been declining in the worsted industry during about the last five years (Brearley, 1964, 1965). It seems, therefore, difficult to explain a difference of incidence of 160 to one by the relative proportions of mules used in the two industries.

Differences in the working methods between the two industries may provide an explanation.

The appearance of mule spinners' cancer in cotton workers followed the introduction of mineral oil as a lubricant, and the same oil has been used in the wool industry (Brockbank, 194I; Thornton, 1966, personal communication). ${ }^{1}$ Twort and Ing (1928), working with groups of 100 mice, found that waste oil from cotton-spinning machines produced two warts and no tumours, whereas the waste oil from wool-spinning machines produced no warts and no tumours. (By contrast, shale oil, the most potent carcinogen, produced 13 warts and I8 tumours.) This comparison between oil from cotton and from wool machines is, in view of the small figures, probably interesting rather than important.

The faller shaft in wool mules is said to be a few inches lower, thus the thigh rather than the groin bears against the oily bar. In fact, the height of the faller shaft from the ground varies from 28 to

\footnotetext{
1 No further references to this statement have been found in the literature. However, the statement has been confirmed in enquiries made at The Wool Industries Research Association, The Cotton and Man-made Fibres Research Association (Shirley Institute), oil blenders and several textile mills.
} 
32 in. ( $7 \mathrm{I}$ to $8 \mathrm{I} \mathrm{cm}$.), irrespective of the type of mule (Catling, 1966, personal communication).

The temperature in wool-spinning sheds is lower than in cotton-spinning sheds, and consequently the operative wears more clothes. Robertson (1926), in propounding his theory of mechanical irritation as the cause, stated that the wool mule spinners escaped because they wore a soft undergarment. That an extra layer of oil-soaked clothing is a protection against the development of skin cancer is a difficult idea to maintain.

Perhaps a better argument against these last two suggestions is that mule spinners' cancer occurs not infrequently on exposed parts, such as the face and forearms (Home Office, 1926; Robertson, 1926; Southam, 1927; Irvine, 1935), although earlier writers had believed that the disease was confined to the scrotum (Leitch, 1924). If the position of the faller bar, or if the layers of clothing, made any difference to scrotal cancer, they could hardly be expected to affect the incidence of skin cancer on exposed parts. If we look at the published figures of notified cases of skin cancer in mule spinners, we still find the remarkable difference between the two industries (Table II).

\section{TABLE II}

Skin Cancer in Mule SPINNers (NOTIFIEd CASES) 1920-43 (AFTER HENRY, I946)

\begin{tabular}{l|r|c|c}
\hline & Total & Scrotal Area & Other Skin Sites \\
\cline { 2 - 4 } $\begin{array}{l}\text { Cotton } \\
\text { Wool }\end{array}$ & 1,229 & 793 & 436 \\
2 & -1 & 2 \\
\hline
\end{tabular}

${ }^{1}$ The three deaths recorded by Henry (1946) in wool mule spinners in the period 1911-38 do not appear among these cases he records as notified from 1920 to 1943 .

Most of the other possible explanations for this difference relate to the probability of there being less oil in the wool shed. The cops are wider in wool mules, and therefore the spindles are farther apart. Also, in wool mules the spindle speed is considerably slower, so that the bearings are oiled only twice or three times a week (modern ball bearings are lubricated about once a year) compared with two or three times a day in cotton sheds (Table III).

Finally, it has been suggested that the animal oils in the wool in some way protect against the carcinogenic action of the lubricating oil. It may be pertinent to note that Twort and Twort (I93r) found that the addition of lanolin or sperm oil to a
TABLE III

Comparison of CotTon and Wool Mules

\begin{tabular}{|c|c|c|c|}
\hline & Cotton & Worsted ${ }^{1}$ & Woollen \\
\hline $\begin{array}{l}\text { Spindle speed } \\
\quad(\mathrm{I}, \infty 00 \text { rev./min.) } \\
\text { Spindle pitch (in.) } \\
\text { Oiling frequency }\end{array}$ & $\begin{array}{l}8-10 \\
1 \frac{1}{16}-1 \frac{3}{8} \\
\text { Twice } \\
\text { daily }\end{array}$ & $\begin{array}{c}5-7 \\
\text { I } \frac{3}{4} \\
\text { Daily to } \\
\text { twice weekly }\end{array}$ & $\begin{array}{c}3-4 \\
2+-2 \frac{1}{2} \\
\text { Weekly }\end{array}$ \\
\hline $\begin{array}{l}\text { Height of faller shafts } \\
\text { (in.) } \\
\text { General ambient } \\
\text { temperature }\left({ }^{\circ} \mathrm{F} .\right)\end{array}$ & 28 to 32 & $\begin{array}{l}\text { independent } \\
\text { of mule }\end{array}$ & type \\
\hline
\end{tabular}

From data supplied by Catling, 1966, personal communication.

${ }^{1}$ The wool industry has two main branches, the worsted and the woollen industries.

${ }^{2}$ Distance between centres of adjacent spindles.

carcinogenic oil decreased its carcinogenicity. Further, certain non-mineral oils are added to the wool fibres at the spinning stage as a lubricant (cotton fibres contain waxes and are therefore self-lubricating). It may be that these added nonmineral spinning oils contribute to the supposed protective action of the animal oils, such as lanolin, in the wool.

Whatever the real explanation, it remains that here was an opportunity for industrial medicine to learn about some factors responsible for skin cancer. Did the different spacing of the spindles or their speeds and the consequent different quantities of oil used reduce the contact below some critical amount, or was there something in the wool oil which provided protection? If it did, how did it act? Had the answer been found, more might be known about the prevention of industrial skin cancer. But the opportunity has been missed, for preventive measures were taken some I3 years ago with the Mule Spinning Regulations. And now, mule spinning has all but disappeared from the cotton industry.

We should like to thank Dr. H. Catling, of the Cotton Silk and Man-made Fibres Research Association, for advice on technical matters. Information has been willingly given by the Wool Industries Research Association, various mills, and oil manufacturers

\section{REFERENCES}

Brearley, A. (1964). Worsted, p. 94, Pitman, London. - (1965). The Woollen Industry, p. 84, Pitman, London.

Brockbank, E. M. (194I). Mule Spinners Cancer. H. K. Lewis, London.

and Stopford, J. S. B. (1927). Brit. med. F., 2, 993.

Davies, C. Stella (1963). North Country Bred, p. 16. Routledge and Kegan Paul, London.

Henry, S. A. (1937). Amer. F. Cancer, 31, 28. 
(1946). Cancer of the Scrotum in Relation to Occupation. Oxford University Press, London.

Home Office (1926). Report of the Departmental Committee appointed to consider evidence as to the occurrence of epithaliomatous ulceration among mule spinners. H.M.S.O., London.

Irvine, E. D. (1935). Brit. med. F., 2, 996.

Leitch, A. (1924). Ibid., 2, 94 I.
Registrar-General (1938). Decennial Supplement (England and Wales), 1931. Part IIa; Occupational Mortality. H.M.S.O., London.

Robertson, J. (1926). Brit. med. F., 2, 1181.

Southam, A. H. (1927). Ibid., 1, 366. and Wilson, S. R. (1922). Ibid., 2, 97I.

Twort, C. C., and Ing, H. R. (1928). Lancet, 1, 752. and Twort, J. M. (1931). F. industr. Hyg., 13, 204. 